\title{
Pharmacological Characteristics of Choline Transport System in Mouse Cerebral Cortical Neurons in Primary Culture
}

\author{
Masataka Kishi, Seitaro Ohkuma, Fu-Hai Ma and Kinya Kuriyama* \\ Department of Pharmacology, Kyoto Prefectural University of Medicine, Kamikyo-ku, Kyoto c02, Japan
}

Received August 11, 1990 Accepted November 16, 1990

\begin{abstract}
The characteristics of $\left[{ }^{3} \mathrm{H}\right]$ choline transport with high affinity were investigated using primary cultured neurons obtained from the mouse cerebral cortex. $\left[{ }^{3} \mathrm{H}\right]$ Choline uptake was saturable as a function of extracellular $\left[{ }^{3} \mathrm{H}\right]$ choline concentration. Analysis by Lineweaver-Burk plot revealed that $\left[{ }^{3} \mathrm{H}\right]$ choline was transported into neurons by a high affinity transport system with a $\mathrm{K}_{\mathrm{m}}$ value of $19.8 \pm 0.8 \mu \mathrm{M}$ and $V_{\max }$ value of $0.334 \pm 0.022 \mathrm{nmol} / \mathrm{mg}$ protein $/ \mathrm{min}$. This high affinity transport of $\left[{ }^{3} \mathrm{H}\right]$ choline was significantly inhibited by the withdrawal of sodium from the incubation medium, incubation at low temperature $\left(4^{\circ} \mathrm{C}\right)$ and addition of metabolic inhibitors such as monoiodoacetate. These results indicate that the high affinity $\left[{ }^{3} \mathrm{H}\right]$ choline uptake in primary cultured neurons is sodium- and energy-dependent. Hemicholinium-3 also showed a competitive inhibition on the $\left[{ }^{3} \mathrm{H}\right]$ choline transport. Depolarization by high $\mathrm{K}^{+}$induced an enhancement of the $\left[{ }^{3} \mathrm{H}\right]$ choline uptake in the presence of $\mathrm{Ca}^{2+}$. The crude synaptosomal fraction obtained from primary cultured neurons possessed approximately forty-fold higher synthesizing activity of $\left[{ }^{3} \mathrm{H}\right]$ acetylcholine from $\left[{ }^{3} \mathrm{H}\right]$ choline than that found in the homogenate preparation of cultured neurons. The present results strongly suggest that the primary cultured neurons used in this study possess a sodium- and energy-dependent high-affinity choline uptake system as well as a synthesizing system for acetylcholine. Possible usefulness of these neurons for investigating neuronal uptake of choline and its functional role in the biosynthesis of acetylcholine are also suggested.
\end{abstract}

It has been well-documented that choline in the brain has at least two functional roles, one is a precursor of acetylcholine and another is a component of phosphatidylcholine and sphingomyelin constituting membrane lipids (1). The evidences reported have indicated that choline accumulated in the brain by the sodiumdependent and high affinity transport system (2) originates from hepatic and dietary supplies (3). Although Blusztajin and his coworkers have reported that the de novo synthesis of

\footnotetext{
* To whom correspondence should be addressed.
}

choline in the brain plays a minor role in the metabolism of choline in the brain (4), a high rate of conversion of choline to acetylcholine in synaptosomes has been documented (5-7). These evidences, therefore, strongly suggest that the sodium-dependent and high affinity transport system for choline may be an important regulatory step for the synthesis of the neurotransmitter acetylcholine $(2,8,9)$. In addition, synaptosomes have been considered to be the prominent site for choline transport $(8,10)$.

The brain tissue consists of several types of 
cells such as neurons, glial cells and capillary endothelial cells, and the proportion of neurons in the brain has been calculated to be approximately $40 \%$ (11). In addition, more than $40 \%$ of the protein found in the synaptosomal fraction. which is often used for the neurochemical studies, originates from glial cells (12). In fact, a choline transport system has been reported to be present in astrocytes (13) and brain microvessels (14). These results suggest that the characteristics and activity of the choline transport system determined in cerebral slices and synaptosomal fraction may not be necessarily reflect those in neurons. In this study, we have attempted to investigate the pharmacological characteristics of the choline transport system using mouse cerebral cortical neurons in primary culture.

\section{MATERIALS AND METHODS}

\section{Dissociation and primary culture of neurons}

Dissociation and primary culture of cerebral cortical neurons were carried out as described previously (15). In brief, the neopallium free of meninges obtained from 15-day-old fetus of ddy strain mouse was minced, trypsinized and centrifuged. The pellet obtained was then suspended in modified Eagle's minimum essential medium (MEM, pH 7.4) (15) supplemented with $15 \%$ fetal calf serum. The cell suspension was added into a Corning culture dish $(60 \mathrm{~mm}$ in diameter) pretreated with poly-L-lysine. On the 3rd day of seeding cells, the culture medium was changed to modified MEM containing $15 \%$ horse serum and 20 $\mu \mathrm{M}$ cytosine arabinoside, and the cells were incubated for $24 \mathrm{hr}$ to suppress the proliferation of non-neuronal cells such as astrocytes. Following the exposure of cells to cytosine arabinoside, neurons were cultured in modified MEM with $15 \%$ horse serum which was exchanged every 4 days to newly prepared modified MEM containing $15 \%$ horse serum. The contamination of astrocytes in the cultured cell population prepared by the method described above was less than $5 \%(15,16)$, as examined by an immunohistochemical tech- nique using the antibody to glial fibrillary acidic protein, a specific marker for astrocytes. Morphological examinations including transmission electron microscopy have revealed the formation of synapses with asymmetric membrane thickening and vesicle-filled boutons (16). These results indicate that the cells used in this study possess the morphological features specific to neurons.

\section{Measurement of $I^{3} \mathrm{H} / \mathrm{choline}$ uptake into cultured neurons}

Following aspiration of culture medium, 14day-old neurons were washed 3 times with ice-cold Krebs-Ringer bicarbonate buffer

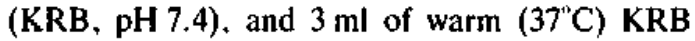
was added into a culture dish followed by incubation at $37^{\circ} \mathrm{C}$ for $20 \mathrm{~min}$. After this preincubation, $3 \mathrm{ml}$ of fresh warm KRB was added into a culture dish. The reaction was initiated by the addition of $20 \mu \mathrm{M}\left[{ }^{3} \mathrm{H}\right]$ choline into a dish and then incubated at $37^{\circ} \mathrm{C}$ for $6 \mathrm{~min}$. The reaction was terminated by rapid aspiration of incubation medium containing $\left[{ }^{3} \mathrm{H}\right]$ choline and subsequent rinsing of the dish 3 times with ice-cold KRB. This procedure for terminating the reaction was carried out within $45 \mathrm{sec}$. Neurons were then scraped off from a culture dish with $1 \mathrm{ml}$ of $0.1 \mathrm{M}$ $\mathrm{NaOH}$. An aliquot of alkaline digested cells was neutralized by $0.1 \mathrm{M}$ acetic acid and transferred to a scintillation vial containing 10 $\mathrm{ml}$ of Triton-toluene scintillator [toluene (containing $5 \mathrm{~g}$ PPO and $0.3 \mathrm{~g}$ POPOP per liter): Triton $X-100=2: 1]$ for the measurement of radioactivity accumulated in neurons. The net uptake of $\left[{ }^{3} \mathrm{H}\right]$ choline was calculated by correcting for intercellular space as determined by $\left[{ }^{3} \mathrm{H}\right]$ inulin (17). For examining the effect of various metabolic inhibitors on $\left[{ }^{3} \mathrm{H}\right]$ choline uptake, neurons were preincubated in culture medium containing $15 \%$ horse serum in the presence of various metabolic inhibitors at $37^{\circ} \mathrm{C}$ for $15 \mathrm{hr}$ as previously described (17). The trypan blue exclusion test revealed that such treatments did not cause any alterations in the ability to exclude trypan blue dye in treated neurons as compared with that in non- 
treated neurons. Sodium-free medium was prepared by equimolar displacement of sodium by lithium. In order to examine the effect of hemicholinium-3, this drug was added into the incubation medium immediately before the addition of $\left[{ }^{3} \mathrm{H}\right]$ choline.

Measurement of I $^{3}$ Hacetylcholine (ACh) formation from ${ }^{3} \mathrm{H}$ /choline

To investigate whether or not $\left[{ }^{3} \mathrm{H}\right] \mathrm{ACh}$ was synthesized from $\left[{ }^{3} \mathrm{H}\right]$ choline in neurons used in this study, we examined the ratio of synthesized $\left[{ }^{3} \mathrm{H}\right] \mathrm{ACh}$ to $\left[{ }^{3} \mathrm{H}\right]$ choline accumulated in the synaptosomal fraction prepared from neurons cultured for 14 days. Neurons were homogenized in $0.32 \mathrm{M}$ sucrose with a Teflon homogenizer and then centrifuged at $1,000 \times$ $g$ at $4^{\circ} \mathrm{C}$ for $10 \mathrm{~min}$. The supernatant obtained was subsequently centrifuged at $20,000 \times g$ at $4^{\circ} \mathrm{C}$ for $20 \mathrm{~min}$, and the resultant pellet was used as the crude synaptosomal fraction. This fraction was incubated with KRB containing 1 $\mu \mathrm{Ci}$ of $\left[{ }^{3} \mathrm{H}\right]$ choline in the presence of $100 \mu \mathrm{M}$ physostigmine at $37^{\circ} \mathrm{C}$ for $1 \mathrm{hr}$. Determination of $\left[{ }^{3} \mathrm{H}\right] \mathrm{ACh}$ converted from $\left[{ }^{3} \mathrm{H}\right]$ choline was carried out by the method described by Shea and Aprison (18). The recovery of $\left[{ }^{3} \mathrm{H}\right] \mathrm{ACh}$ was more than $70 \%$, and $\left[{ }^{3} \mathrm{H}\right]$ choline contamination of the separated $\left[{ }^{3} \mathrm{H}\right] \mathrm{ACh}$ was less than $5 \%$.

\section{Protein measurement}

The content of protein in primary cultured neurons was determined by the method of Lowry et al. (19) using bovine serum albumin as a standard.

\section{Materials used}

$\left[{ }^{3} \mathrm{H}\right]$ Choline $(80 \mathrm{Cl} / \mathrm{mmol})$ and $\left[{ }^{3} \mathrm{H}\right]$ inulin $(164 \mathrm{mCi} / \mathrm{g})$ were obtained from New England Nuclear (Boston. U.S.A.). Gibco Laboratories (Chagrin Falls, U.S.A.) was a source of fetal calf serum and horse serum. Eagle's minimum essential medium (powder), bovine serum albumin (fraction $\mathrm{V}$, powder) and trypsin were purchased from Nissui Seiyaku (Tokyo, Japan), Miles Laboratories, Inc. (Kankakee. U.S.A.) and Sigma Chemicals Co. (St. Louis, U.S.A.), respectively. Cytosine arabinoside was a gift of Nippon Shinyaku Co., Ltd. (Kyoto, Japan). Other chemicals used were obtained locally and analytical grade.

\section{RESULTS}

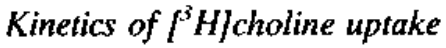

Figure 1 shows the time course of $\left[{ }^{3} \mathrm{H}\right]-$ choline uptake in primary cultured neurons in the presence of $5 \mu \mathrm{M}\left[{ }^{3} \mathrm{H}\right]$ choline at $4^{\circ} \mathrm{C}$ and $37^{\circ} \mathrm{C}$. At $37^{\circ} \mathrm{C},\left[{ }^{3} \mathrm{H}\right]$ choline uptake showed a

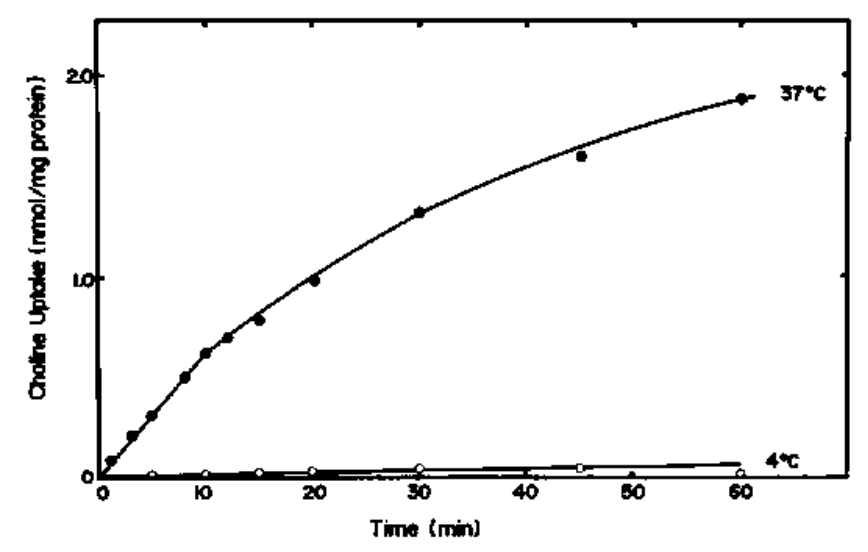

Fig. 1. Time course of $\left.\left.\right|^{3} \mathbf{H}\right]$ choline uptake into mouse cerebral cortical neurons in primary culture. Following the preincubation of neurons cultured for 14 days in Krebs-Ringer bicarbonate buffer (KRB, pH 7.4) at $37^{\circ} \mathrm{C}$ for $20 \mathrm{~min}$. neurons were further incubated in fresh $\mathrm{KRB}$ in the presence of $5 \mu \mathrm{M}\left[{ }^{3} \mathrm{H}\right] \mathrm{choline}$ at $4^{6} \mathrm{C}$ or $37 \mathrm{C}$. Each value represents the mean of 2 separate experiments. 
linear increase until $\mathbf{1 0}$ min after the initiation of the reaction, and then the rate of increase in $\left[{ }^{3} \mathrm{H}\right]$ choline uptake was gradually decreased. In contrast, it was found that a small amount of $\left[{ }^{3} \mathrm{H}\right]$ choline was accumulated in neurons at $4^{\circ} \mathrm{C}$. Based on these data, the initial rate of $\left[{ }^{3} \mathrm{H}\right]$ choline uptake at $37^{\circ} \mathrm{C}$ was determined during first $6 \mathrm{~min}$ after the addition of $\left[{ }^{3} \mathrm{H}\right]$ choline.

The rate of $\left[{ }^{3} \mathrm{H}\right]$ choline uptake by neurons as a function of extracellular $\left[{ }^{3} \mathrm{H}\right]$ choline concentration is shown in Fig. 2A. The accumula- tion of $\left[{ }^{3} \mathrm{H}\right]$ choline in neurons showed a significant elevation with the increase of $\left[{ }^{3} \mathrm{H}\right]$ choline concentration in the incubation medium and reached its plateau at approximately $100 \mu \mathrm{M}$, indicating that $\left[{ }^{3} \mathbf{H}\right]$ choline was transported into neurons in a saturable manner. The Lineweaver-Burk plot revealed that $\left[{ }^{3} \mathrm{H}\right]$ choline was transported by a high affinity uptake system with a $K_{\mathrm{m}}$ value of $19.8 \pm 0.8 \mu \mathrm{M}$ and $B_{\max }$ value of $334 \pm 22$ $\mathrm{pmol} / \mathrm{mg}$ protein $/ \mathrm{min}$ (Fig. 2B). This high affinity transport of $\left[{ }^{3} \mathrm{H}\right]$ choline was competi-
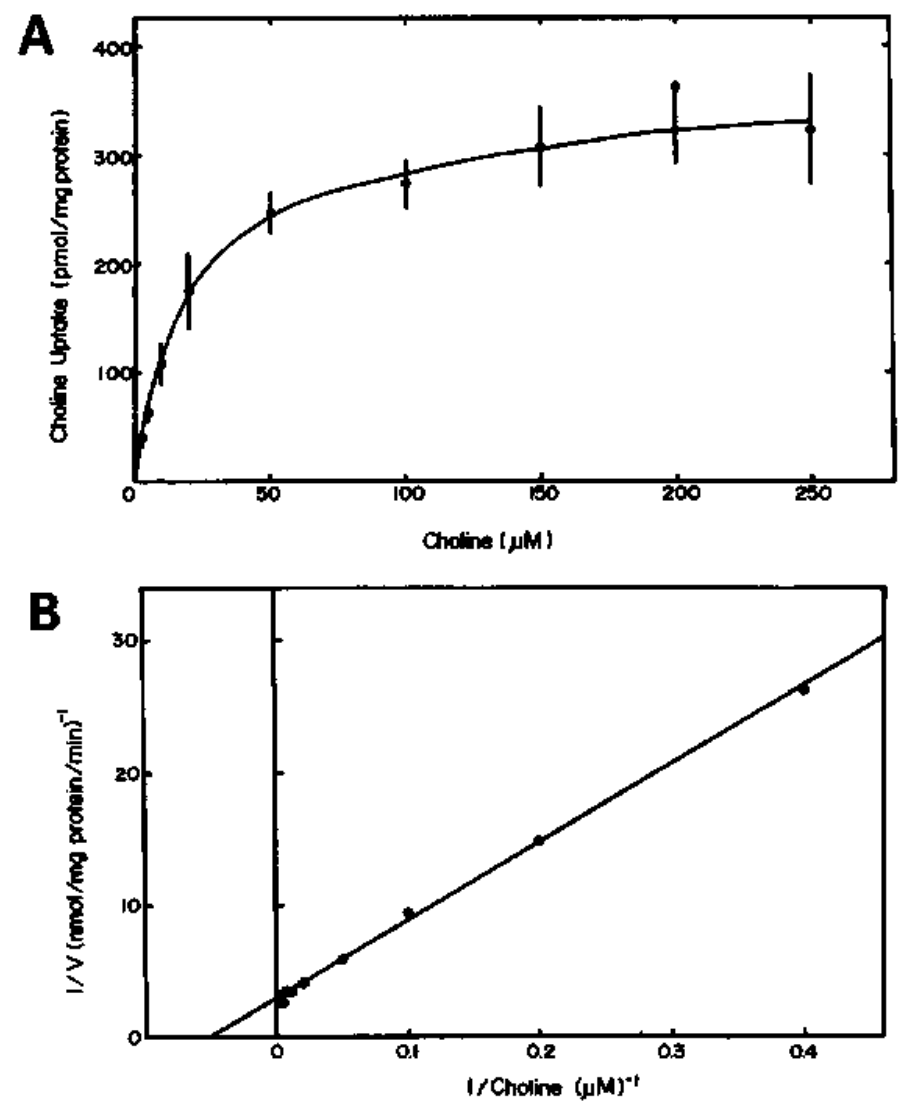

Fig. 2. [ $\left.{ }^{3} \mathrm{H}\right]$ Choline uptake by mouse cerebral cortical neurons in primary culture. (A) Rate of $\left[^{3} \mathrm{H}\right] \mathrm{choline}$ uptake as a function of external $\left[{ }^{3} \mathrm{H}\right]$ choline concentration. Following the preincubation of neurons cultured for 14 days in Krebs-Ringer bicarbonate buffer (KRB, pH 7.4) at $37^{\circ} \mathrm{C}$ for $20 \mathrm{~min}$, neurons were further incubated in fresh KRB in the presence of various concentrations of $\left[{ }^{3} \mathrm{H}\right]$ choline at $37^{\circ} \mathrm{C}$ for $6 \mathrm{~min}$. The determination of $\left[{ }^{3} \mathrm{H}\right]$ choline accumulated in neurons was carried out as described in Materials and Methods. Each value represents the uptake of $\left[{ }^{3} \mathrm{H}\right]$ choline for $6 \mathrm{~min}$ and the mean \pm S.E. obtained from 5 separate experiments. (B) Lineweaver-Burk plot of $\left[{ }^{3} \mathrm{H}\right]$ choline uptake by mouse cerebral cortical neurons cultured for 14 days. The $K_{m}$ and $B_{\max }$ values were $19.8 \pm 0.8 \mu \mathrm{M}$ and $0.334 \pm 0.022 \mathrm{nmol} / \mathrm{mg}$ protein $/ \mathrm{min}$. respectively. 
tively inhibited by hemicholinium-3, a wellknown inhibitor of choline uptake (Fig. 3). The $K_{i}$ value of hemicholinium- 3 for choline uptake in primary cultured neurons was found to be approximately $31.5 \mu \mathrm{M}$.

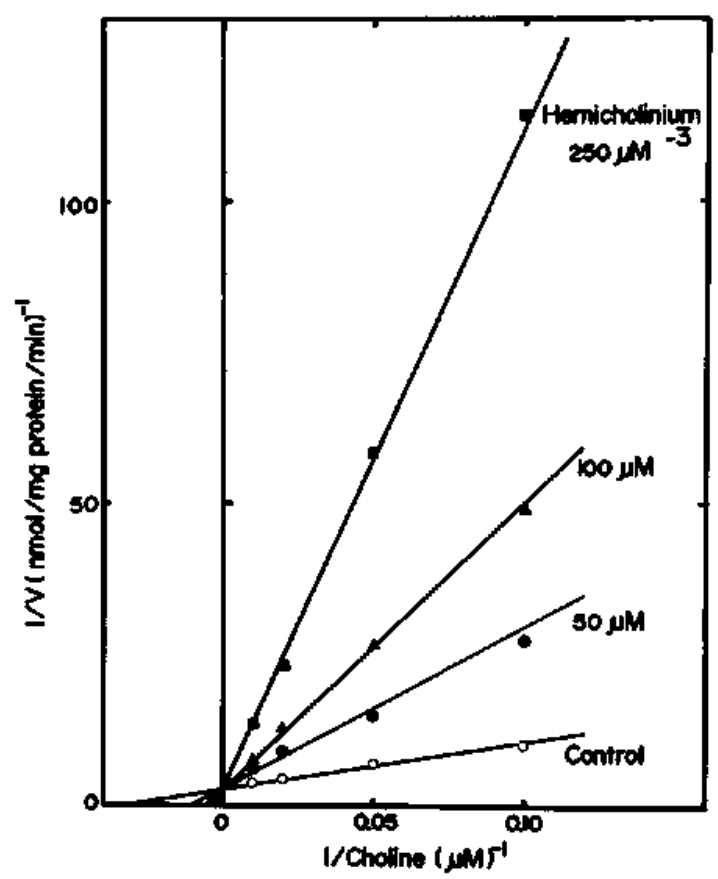

Fig. 3. Effect of hemicholinium-3 on $\left[{ }^{3} \mathrm{H}\right]$ choline uptake by mouse cerebral cortical neurons in primary culture. Following the preincubation of 14-day-old neurons in culture with Krebs-Ringer bicarbonate buffer (KRB, pH 7.4) at $37^{\circ} \mathrm{C}$ for $20 \mathrm{~min}$, neurons were further incubated with fresh KRB in the presence of $20 \mu \mathrm{M}\left[{ }^{3} \mathrm{H}\right]$ choline and various concentrations (50$250 \mu \mathrm{M})$ of hemicholinium-3 at $37^{\circ} \mathrm{C}$ for $6 \mathrm{~min}$. Hemicholinium-3 was added into KRB immediately before the addition of $\left[{ }^{3} \mathrm{H}\right]$ choline into KRB. Each value represents the mean of 3 separate experiments.

Effect of various metabolic inhibitors and sodium withdrawal on $l^{3} \mathrm{H} / \mathrm{choline}$ uptake

In order to examine whether or not the high affinity uptake of $\left[{ }^{3} \mathrm{H}\right]$ choline transport in primary cultured neurons is sodium- and energy-dependent, the effects of various metabolic inhibitors and sodium withdrawal from the incubation medium were investigated. Sodium withdrawal from the incubation medium caused a remarkable reduction in $\left[{ }^{3} \mathrm{H}\right]$ choline uptake, although ouabain caused no significant inhibition (Table 1). One millimolar 2,4-dinitrophenol, $1.0 \mathrm{mM}$ monoiodoacetate and $1.0 \mathrm{mM}$ sodium azide, to which neurons were exposed during preincubation for $20 \mathrm{~min}$ in the absence of $\left[{ }^{3} \mathrm{H}\right]$ choline as well as an incubation period for $6 \mathrm{~min}$ with $\left[{ }^{3} \mathrm{H}\right]$ choline, induced no significant alteration in $\left[{ }^{3} \mathrm{H}\right]$ choline accumulation. However, following exposure of the neurons to $10 \mu \mathrm{M}$ monoiodoacetate in culture medium at $37^{\circ} \mathrm{C}$ for $15 \mathrm{hr},\left[{ }^{3} \mathrm{H}\right]$ choline transport was found to be significantly reduced. In contrast, the treatment of neurons with 2,4-dinitrophenol for $15 \mathrm{hr}$ did not induce such a suppression of $\left[{ }^{3} \mathrm{H}\right]$ choline uptake (Table 1 ).

Effect of addition of a high concentration of potassium and removal of calcium on $I^{3} H /$ choline uptake

The effects of depolarization induced by the exposure of neurons to a high concentration $(60 \mathrm{mM})$ of $\mathrm{KCl}$ and withdrawal of $\mathrm{Ca}^{2+}$ from the incubation medium on $\left[{ }^{3} \mathrm{H}\right]$ choline were examined (Table 2). The addition of $60 \mathrm{mM} \mathrm{KCl}$ into the preincubation medium enhanced $\left[{ }^{3} \mathrm{H}\right]$ choline uptake in the presence of $\mathrm{Ca}^{2+}$. In contrast, when neurons were preincubated with $60 \mathrm{mM} \mathrm{KCl}$ in the absence of $\mathrm{Ca}^{2+},\left[{ }^{3} \mathrm{H}\right]$ choline uptake was found to be reduced. In addition, choline uptake by primary cultured neurons in medium with 60 mM KCl or without $\mathrm{Ca}^{2+}$ following preincubation with KRB was significantly reduced.

Synthesis of $l^{3} \mathrm{H} / \mathrm{ACh}$ from $P^{3} \mathrm{H} / \mathrm{choline}$ in the crude synaptosomal fraction prepared from cultured neurons

In primary cultured neurons, approximately $0.4 \%$ of accumulated $\left[{ }^{3} \mathrm{H}\right]$ choline was found to be converted to $\left[{ }^{3} \mathrm{H}\right]$ ACh (Table 3). On the other hand, it was found that the crude synaptosomal fraction prepared from primary cultured neurons converted $15.3 \%$ of the accumulated $\left[{ }^{3} \mathrm{H}\right]$ choline to $\left[{ }^{3} \mathrm{H}\right] \mathrm{ACh}$. 
Table 1. Effects of metabolic inhibitors and sodium withdrawal on $\left[{ }^{3} \mathrm{H}\right]$ choline uptake in mouse cerebral cortical neurons in primary culture

\begin{tabular}{lcc}
\hline $\begin{array}{l}\text { Metabolic } \\
\text { inhibitors }\end{array}$ & $\begin{array}{c}{\left[{ }^{3} \mathrm{H}\right] \text { Choline uptake }} \\
(\mathrm{nmol} / \mathrm{mg} \text { protein/min) }\end{array}$ & $\begin{array}{c}\text { Number of } \\
\text { experiments }\end{array}$ \\
\hline $\begin{array}{l}\text { None } \\
\text { Sodium-free }\end{array}$ & $0.178 \pm 0.010$ & 5 \\
Ouabain & $0.109 \pm 0.007^{* *}$ & 3 \\
$100 \mu \mathrm{M}$ & & \\
$1 \mathrm{mM}$ & $0.158 \pm 0.010$ & 3 \\
2.4-Dinitrophenol & $0.162 \pm 0.011$ & 5 \\
$100 \mu \mathrm{M}$ & $0.157 \pm 0.016$ & 3 \\
$1 \mathrm{mM}$ & $0.191 \pm 0.006$ & 5 \\
$100 \mu \mathrm{M}$ u) & $0.194 \pm 0.008$ & 3 \\
Monoiodoacetate & $0.194 \pm 0.010$ & 5 \\
$1 \mathrm{mM}$ & $0.102 \pm 0.004^{* *}$ & 3 \\
$10 \mu \mathrm{M}^{\mathrm{ij}}$ & & 5 \\
Sodium azide & $0.157 \pm 0.019$ & 5 \\
$1 \mathrm{mM}$ &
\end{tabular}

Following the preincubation of neurons with Krebs-Ringer bicarbonate buffer (KRB, pH 7.4) in the presence of various metabolic inhibitors at $37^{\circ} \mathrm{C}$ for $20 \mathrm{~min}$, neurons were further incubated with fresh KRB containing $20 \mu \mathrm{M}\left[{ }^{3} \mathrm{H}\right]$ choline and each inhibitor at $37^{\circ} \mathrm{C}$ for $6 \mathrm{~min}$. ${ }^{\prime \prime}$ Neurons were incubated with modified Eagle's minimum essential medium supplemented with $15 \%$ horse serum in the presence of each metabolic inhibitor at $37^{\circ} \mathrm{C}$ for $15 \mathrm{hr}$ and then their $\left[{ }^{3} \mathrm{H}\right] \mathrm{choline}$ uptake was determined. Each value represents the mean \pm S.E. ${ }^{*} \mathrm{P}<0.05,{ }^{* *} \mathrm{P}<0.01$, compared with the control (None value).

Table 2, Effects of sodium, potassium and calcium on [ $\left.{ }^{3} \mathrm{H}\right]$ choline uptake in mouse cerebral cortical neurons in primary culture

\begin{tabular}{|c|c|c|c|}
\hline $\begin{array}{l}\text { Preincubation } \\
\text { medium }\end{array}$ & $\begin{array}{l}\text { Incubation } \\
\text { medium }\end{array}$ & $\begin{array}{l}{\left[{ }^{3} \mathrm{H}\right] \text { Choline uptake }} \\
\left(\% \text { of control }{ }^{2 /}\right)\end{array}$ & $\begin{array}{l}\text { Number of } \\
\text { experiments }\end{array}$ \\
\hline $\mathrm{KRB}^{\mathrm{by}}$ & KRB & $100.0 \pm 4.6$ & 3 \\
\hline $30 \mathrm{mM} \mathrm{KCl}$ & KRB & $88.9 \pm 2.6$ & 4 \\
\hline $60 \mathrm{mM} \mathrm{KCl}$ & KRB & $129.8 \pm 4.7^{* *}$ & 7 \\
\hline \multicolumn{4}{|l|}{$30 \mathrm{mM} \mathrm{KCl}$} \\
\hline$+\mathrm{Ca}^{2+}$-free & KRB & $89.0 \pm 3.3$ & 4 \\
\hline \multicolumn{4}{|l|}{$60 \mathrm{mM} \mathrm{KCl}$} \\
\hline$+\mathrm{Ca}^{2+}$-free & KRB & $76.9 \pm 5.3^{*}$ & 7 \\
\hline KRB & $30 \mathrm{mM} \mathrm{KCl}$ & $80.6 \pm 5.3^{*}$ & 3 \\
\hline KRB & $60 \mathrm{mM} \mathrm{KCl}$ & $71.0 \pm 4.3^{* *}$ & 6 \\
\hline KRB & $\mathrm{Ca}^{2+}$-free & $87.8 \pm 3.2^{* *}$ & 6 \\
\hline
\end{tabular}

Neurons were preincubated with various types of "preincubation medium" described in the table at $37^{\circ} \mathrm{C}$ for $20 \mathrm{~min}$, and then further incubated with the "incubation medium ${ }^{n}$ indicated in the table in the presence of $20 \mu \mathrm{M}\left[\left[^{3} \mathrm{H}\right]\right.$ choline at $37^{\circ} \mathrm{C}$ for 6 min. Each value represents the mean \pm S.E. ") Control value (preincubation medium: KRB, incubation medium: $\mathrm{KRB}$ ) was $0.129 \pm 0.006 \mathrm{nmol} / \mathrm{mg}$ protein $/ \mathrm{min} .{ }^{\text {b) }} \mathrm{KRB}$ : Krebs-Ringer bicarbonate buffer $(\mathrm{pH} 7,4) .{ }^{*} \mathrm{P}<0.05,{ }^{* *} \mathrm{P}<$ 0.01 , compared with the control value. 
Table 3. $\left[{ }^{3} \mathrm{H}\right]$ Acetylcholine $\left(\left[{ }^{3} \mathrm{H}\right] \mathrm{ACh}\right)$ formation from $\left[{ }^{3} \mathrm{H}\right]$ choline in primary cultured neurons and in crude synaptosomal fraction obtained from primary cultured neurons

\begin{tabular}{lccc}
\hline Materials & $(\mathrm{N})$ & {$\left[{ }^{3} \mathrm{H}\right.$ [Choline uptake ${ }^{\mathrm{a})}$} & $\begin{array}{c}\text { Conversion to } \\
{\left[{ }^{3} \mathrm{H}\right] \mathrm{ACh}^{\mathrm{h})}}\end{array}$ \\
\hline $\begin{array}{l}\text { Neurons } \\
\begin{array}{l}\text { Synaptosomes } \\
\text { from neurons }\end{array}\end{array}$ & $\mathbf{4}$ & $89.8 \pm 1.7$ & $0.4 \pm 0.1$ \\
\hline
\end{tabular}

Neurons and synaptosomes prepared from neurons were incubated with Krebs-Ringer bicarbonate buffer $(\mathrm{pH} 7.4)$ containing $\left.\mathrm{I} \mu \mathrm{Ci} \mid{ }^{3} \mathrm{H}\right]$ choline in the presence of 100 $\mu \mathrm{M}$ physostigmine at $37^{3} \mathrm{C}$ for $1 \mathrm{hr}$. ${ }^{\text {al }}$ Percentage of total $\left[{ }^{3} \mathrm{H}\right]$ choline added into the culture medium or synaptosomal suspension. ${ }^{\text {h) }}$ Percentage of conversion of accumulated $\left[{ }^{3} \mathrm{H}\right]$ choline to $\left[{ }^{3} \mathrm{H}\right] \mathrm{ACh}$. (N): Number of experiments.

\section{DISCUSSION}

In the present study, we have attempted to investigate the characteristics of the choline transport system in cerebral cortical neurons in primary culture with morphological features specific to neurons such as synaptic formation $(15,16)$ as well as neurochemical properties as cholinergic neurons such as the capacity to metabolize $\mathrm{ACh}(20,21)$, because the available data on pharmacological characteristics on choline transport in primary cultured neurons prepared from mouse cerebral cortex are few.

In these neurons, $\left[{ }^{3} \mathrm{H}\right]$ choline was found to be accumulated by a high affinity transport system. The $\mathrm{K}_{\mathrm{m}}$ value $(19.8 \mu \mathrm{M})$ for choline transport in these neurons was similar to that determined in mouse hippocampal neurons in primary culture (22). On the other hand, the $\mathrm{K}_{\mathrm{m}}$ values for this transport system detected in the synaptosomal fraction from the cerebral cortex and hippocampus have been reported to be in the order of $1 \mu \mathrm{M}$ to $5 \mu \mathrm{M}(8,9,22$ $25)$. In primary cultured neurons used in this study, cholinergic neurons was approximately $5 \%$ of the total cells when examined with an antibody against choline acetyltransferase (data not shown) and more than $80 \%$ of the neurons were GABAergic neurons (16). Therefore, such a low population of cholinergic neurons may result in the low $\mathrm{K}_{\mathbf{m}}$ value for choline transport observed in this study. In addition, the $K_{m}$ value for high affinity transport of choline in cerebral cortical neurons prepared from chick embryo has been reported to be $2.6 \mu \mathrm{M}$ (26). The difference in $K_{m}$ values between primary cultured neurons obtained from the mouse and chick may be due to the difference of animal species used for preparing neurons. However, the exact reason why the $K_{m}$ value of $\left[{ }^{3} \mathrm{H}\right]$ choline uptake in cultured neurons is somewhat higher than these observed in synaptosomes and slices prepared from rodent brains is unclear at present.

Sodium withdrawal from the incubation medium diminished the high affinity $\left[{ }^{3} \mathrm{H}\right]$ choline uptake in primary cultured neurons, indicating that this transport system is sodium-dependent as reported in slices and synaptosomes $(8,24,27-29)$. One millimolar ouabain slightly reduced $\left[{ }^{3} \mathrm{H}\right]$ choline uptake, although it was not statistically significant. It seems likely, therefore, that the high affinity transport system for choline in primary cultured neurons may be sodium-dependent. This transport system is also temperaturedependent, since only a small amount of $\left[{ }^{3} \mathrm{H}\right]$ choline is accumulated at $4^{\circ} \mathrm{C}$. In addition, the exposure of neurons to a low concentration of monoiodoacetate for $15 \mathrm{hr}$ induced a reduction of $\left[{ }^{3} \mathrm{H}\right]$ choline uptake, although short-term (26 min) exposures to various metabolic inhibitors such as monoiodoacetate and 2,4-dinitrophenol exhi- 
bited no significant alteration in the activity of $\left[{ }^{3} \mathrm{H}\right]$ choline transport in primary cultured neurons. We also reported previously that the long-term exposure of cultured neurons to these metabolic inhibitors induced the decrease of the high affinity transports of taurine and GABA (17). These evidences, therefore, lead to the conclusion that primary cultured neurons may have low permeability to these metabolic inhibitors, which consequently exhibit poor inhibitory action on the energy generating system. In addition, several investigators similarly found the ineffectiveness or low effectiveness of 2,4-dinitrophenol and cyanides on choline uptake in synaptosomes $(9,24)$, suggesting that choline uptake might not be directly coupled with the ATP generating systems. The real meaning of the weak inhibitory actions of metabolic inhibitors on choline uptake in primary cultured neurons remains to be elucidated in future studies.

Hemicholinium-3 is known to be a competitive inhibitor for choline uptake in cerebral synaptosomes $(30,31)$. In the primary cultured neurons used in the present study, hemicholinium-3 also showed a competitive inhibition on high affinity $\left[{ }^{3} \mathrm{H}\right]$ choline uptake, which indicates that this uptake of $\left[{ }^{3} \mathrm{H}\right]$ choline is mediated by a hemicholinium-sensitive and carrier-mediated transport system. The $\mathbf{K}_{\mathbf{i}}$ value of hemicholinium- 3 for choline transport was found to be approximately $31.5 \mu \mathrm{M}$. This $K_{\mathrm{i}}$ value is similar to that in the synaptosomes of rat brain (30). On the other hand, the $K_{i}$ values of hemicholinium-3 observed in the synaptosomal fractions of rodent brain have been reported to be $25 \mathrm{nM}$ to $1.1 \mu \mathrm{M}$ (8, $9,31)$. These $K_{i}$ values are lower than the $K_{i}$ value found in the primary cultured neurons used in this study. At present, however, the reason for this difference in $K_{i}$ values is not clear.

Several lines of evidence have indicated that neuronal depolarization by high $\mathrm{K}^{+}$induces the increase in choline uptake in brain synaptosomes and slices $(12,27,32,33)$. The application of depolarization by high $\mathrm{K}^{+}$pre- ceding the addition of $\left[{ }^{3} \mathrm{H}\right]$ choline into the incubation medium induced the increase of $\left[{ }^{3} \mathrm{H}\right]$ choline uptake in primary cultured neurons. Furthermore, the application of high $\mathrm{K}^{+}$in the absence of $\mathrm{Ca}^{2+}$ showed the elimination of the high $\mathrm{K}^{+}$effect on $\left[{ }^{3} \mathrm{H}\right]$ choline uptake, suggesting that $\mathrm{ACh}$ released in the presence of $\mathrm{Ca}^{2+}$ may induce the facilitation of choline uptake as demonstrated by Murrin and Kuhar (23) and Roskoski (34). Moreover, the decrease of $\left[{ }^{3} \mathrm{H}\right]$ choline uptake in $\mathrm{Ca}^{2+}$ free medium indicates the requirement of $\mathrm{Ca}^{2+}$ in the choline transport system in primary cultured neurons, which also agrees with the data previously obtained by Murrin and Kuhar (23).

It is noteworthy that the crude synaptosomal fraction prepared from primary cultured neurons possesses a high activity to synthesize $\left[{ }^{3} \mathrm{H}\right] \mathrm{ACh}$ from $\left[{ }^{3} \mathbf{H}\right]$ choline. It has been found that the percentage of radiolabeled choline converted to $\mathrm{ACh}$ is only $0.4 \%$ of the total radioactivity accumulated in primary cultured neurons used in this study. A similar conversion ratio of exogenous choline to $\mathrm{ACh}$ in primary cultured neurons was also reported by Thomas (35). However, crude synaptosomal fractions prepared from primary cultured neurons have converted approximately $15 \%$ of the transported $\left[{ }^{3} \mathrm{H}\right]$ choline to $\left[{ }^{3} \mathrm{H}\right] \mathrm{ACh}$. These results indicate that primary cultured neurons have a capacity to synthesize $\mathrm{ACh}$ from choline accumulated from the extracellular medium and that nerve endings are likely to be one of the sites that synthesize ACh with high activity in primary cultured neurons. This conversion ratio is similar to that in synaptosomes prepared from rat cerebral cortex (36) and is lower than that reported in synaptosomes prepared from rodent brains $(5-7)$. The reason for such a difference in conversion ratio from choline to $\mathrm{ACh}$ is not clear at present.

In summary, primary cultured cerebral cortical neurons possess a high affinity choline transport system which is accelerated by high $\mathrm{K}^{+}$-induced depolarization in the presence of $\mathrm{Ca}^{2+}$. The synaptosomal preparation pre- 
pared from these neurons have a high activity to synthesize ACh from choline. The results obtained in this study, therefore, strongly suggest that primary cultured cerebral cortical neurons may be a useful experimental tool for investigating regulatory mechanisms and/or factors involved in ACh synthesis at synapses.

\section{REFERENCES}

1 Ziesel, S.H.: Dietary choline: biochemistry, physiology, and pharmacology. Annu. Rev. Nutr. 1. $95-121(1981)$

2 Kuhar, M.J., Sethy, V.H., Roth, R.H. and Aghajanian. G.K.: Choline: selective accumulation by central cholinergic neurons. J. Neurochem. 20, $581-593$ (1973)

3 Ansell, G.B. and Spanner, S.: Studies on the origin of choline in the brain of the rat. Biochem. J. 122, 741-750 (1971)

4 Blusztajn, J.K., Ziesel, S.H. and Wurzman, R.J.: Synthesis of lecithin (phosphatidylcholine) from phosphatidylethanolamine in bovine brain. Brain Res. 179. 319-327 (1979)

5 Jope, R.S., Weiler, M.H. and Jenden, D.J.: Regulation of acetylcholine synthesis: control of choline transport and acetylation in synaptosomes. $J$. Neurochem. 30, 949-954 (1978)

6 Richardson. P.J.: Choline uptake and metabolism in affinity-purified cholinergic nerve terminals from rat brain. J. Neurochem. 46, 1251-1255 (1986)

7 Kotas, A.M. and Prince A.K.: High affinity uptake of choline, a marker for cholinergic terminals, is not specific in developing rat brain. Dev. Brain Res. 35, 175-181 (1987)

8 Yamamura, H.I. and Snyder, A.H.: High affinity Iransport of choline into synaptosomes of rat brain. J. Neurochem. 21, 1355-1374 (1973)

9 Haga, T. and Noda, $H_{\text {.; }}$ Choline uptake systems in rat brain synaptosomes. Biochim. Biophys. Acta 291. 564-575 (1973)

10 Sorimachi. M. and Kataoka, K.: High affinity choline uptake: an early index of cholinergic innervation in rat brain. Brain Res. 94, 325-336 (1975)

11 Pope, A.: Neuroglia: Quantitative aspect. In Dynamic Properties of Glial Cells. Edited by Schoffeniels, E.. Frank, G., Hertz, L. and Towers, D.B., p. 13-20. Pergamon Press, Oxford (1978)

12 Henn, F.A., Anderson, D.J. and Rustad. D.G.: Glial contamination of synaptosomal fractions.
Brain Res. 101, 341 - 344 (1976)

13 Massarełli, R., Sensenbrenner, M., Ebel, A. and Mandel. P.: Choline uptake in nerve cell cultures. Neurobiology 4, 293-30) (1974)

14 Shimon, M.. Egozi, Y., Kloog. Y., Sokolovsky, M. and Cohen, S.: Kinetics of choline uptake into isolated rat forebrain microvessels: Evidence of endocrine modulation. J. Neurochem. 50, 17191724 (1988)

15 Ohkuma, S., Tomono, S., Tanaka, K., Kuriyama. K. and Mukainaka, T.: Development of taurine biosynthesizing system in cerebral cortical neurons in primary culture. Int. J. Dev. Neurosci. 4, 383395 (1986)

I6 Kuriyama, K., Tomono, S., Kishi, M., Mukainaka. T. and Ohkuma, S.: Development of $\gamma$-aminobutyric acid (GABA)ergic neurons in cerebral cortical neurons in primary culture. Brain Res. 416, 7-21 (1987)

17 Kishi, K., Ohkuma, S., Kimori. M. and Kuriyama, K.: Characteristics of taurine transport system and its developmental pattern in mouse cerebral cortical neurons in primary culture. Biochim. Biophys. Acta 939,615-623 (1988)

18 Shea, D.A. and Aprison, M.H.: An enzymatic method for measuring picomole quantities of acetylcholine and choline in CNS tissue. Anal. Biochem. 56, $165-177$ (1973)

19 Lowry, O.H., Rosebrough, N.J., Farr, A.L. and Randall, R.J.: Protein measurement with the Folin phenol reagent. J. Biol. Chem. 193, 265274 (1951)

20) Ohkuma, S., Ma, F.-H., Tomono, S., Kishi, M. and Kuriyama, K.: Development of cerebral cholinergic neurons in primary culture. Japan. J. Pharmacol. 43, (Supp.), 148P (1987)

21 Kuriyama, K. and Ohkuma. S.: Cerebral cortical neurons in primary culture and application to neuropharmacological studies. In Methods in Neurosciences, Edited by Conn, P.M., Vol. 2, p. $103-116(1990)$

22 Walker, C.R. and Peacock, J.H.: Development of GABAergic function of dissociated hippocampal cultures from fetal mice. Dev. Brain Res. 2, 541 555 (1982)

23 Murrin, L.C. and Kuhar, M.J.: Activation of high-affinity choline uptake in vitro by depolarizing agents. Mol. Pharmacol. 12, $1082-1090$ (1976)

24 Simon, J.R. and Kuhar. M.J.: High affinity choline uptake: ionic and energy requirements. J. Neurochem. 27, 93-99 (1976)

25 Nordberg, A.: Regional high affinity synaptosomal transport of choline in mouse brain influence of oxotremorine treatment. Life Sci. 23, 937-944 
(1978)

26 Mykita, S., Ferret, B, and Masserelli, R.: Effect of external high potassium and $\mathrm{pH}$ on the uptake of choline in glial and neuronal cells in culture. Neurosci. Res. 12, 681-685 (1987)

27 Simon, J.R., Atweh, S. and Kuhar, M.J.: Sodium-dependent high affinity choline uptake: a regulatory step in the synthesis of acetylcholine. J. Neurochem. 26, $909-922$ (1976)

28 Polak. R.L., Molenaar, P.C. and van Gelder. M.: Acetykholine metabolism and choline uptake in cortical slices. J. Neurochem. 29, 477-485 (1977)

29 Batzold, F., DeHeaven. R.. Kuhar, M.J. and Birdsall, N.: Inhibition of high affinity choline uptake. Structure activity studies. Biochem. Pharmacol. 29, 2413-2416 (1980)

30 Diamond, I. and Milfay, D.: Uptake of $\left[{ }^{3} \mathrm{H}-\right.$ methyl]choline by microsomal, synaptosomal, mitochondrial and synaptic vesicle fractions of rat brain. The effect of hemicholinium. J. Neurochem. 19, $1899-1909$ (1972)

31 Guyenet, P., Lefresne, P., Rossier, J., Beaujouan. J.C. and Glowinski, J.: Inhibition by hemicholinium-3 of $\left[{ }^{14} \mathrm{C}\right]$ acetylcholine synthesis and $\left[{ }^{3} \mathbf{H}\right]$ choline high-affinity uptake in rat striatal synaptosomes. Mol. Pharmacol. 9. 630 - 639 (1973)

32 Mulder, A.H., Yamamura, H.I., Kuhar, M.J. and Snyder, S.H.: Release of acetylcholine from hippocampal slices by potassium depolarization: dependence on high affinity choline uptake. Brain Res. 70, 371-376 (1974)

33 Saelens, J.K.. Simke, J.P., Schuman, J.R. and Allen, M.P.: Studies with agents which intluence acetylcholine metabolism in mouse brain. Arch. Int. Pharmacodyn. Ther. 209. 250-258 (1974)

34 Roskoski, R., Jr.: Acceleration of choline uptake after depolarization-induced acetylcholine release in rat cortical synaptosomes. J. Neurochem. 30, 1357-1361 (1985)

35 Thomas, W.E.: Synthesis of acetylcholine and $\gamma$ aminobutyric acid by dissociated cerebral cortical cells in vitro. Brain Res. 332, 79-89 (1985)

36 Boksa, P.. Mykita, S. and Collier, B.: Arachidonic acid inhibits choline uptake and depletes acetylcholine content in rat cerebral cortical synaptosomes. J. Neurochem. 50, 1309-1318 (1988) 